\title{
Safe Food Handling Knowledge, Attitude and Practice of Food Handlers in Hospital Kitchen
}

\author{
Daru Lestantyo ${ }^{1}$, Adi Heru Husodo ${ }^{2}$, Susi Iravati ${ }^{3}$, Zahroh Shaluhiyah ${ }^{4}$ \\ ${ }_{1,2}$ Dept. Faculty of Medicine Gadjah Mada University, Indonesia \\ ${ }^{3}$ Department of Public Health, Faculty of Medicine Gadjah Mada University, Indonesia \\ ${ }^{4}$ Department of Health Promotion, Faculty of Public Health, Diponegoro University, Indonesia
}

\begin{tabular}{l} 
Article Info \\
\hline Article history: \\
Received Sep 12, 2017 \\
Revised Nov 6, 201 \\
Accepted Nov 26, 20 \\
\hline Keyword: \\
Food handlers \\
Hospital kitchen \\
Safe food handling \\
Safety behaviour
\end{tabular}

\begin{abstract}
Hospital food hygiene plays an important role to patient's health. Studies proved that improper practices and lack of knowledge are contributing factors of foodborne diseases. This study was conducted to determine knowledge, attitude and practice of hospital safe food handling in Semarang, Central Java. A cross sectional study was conducted in two general hospitals' kitchen. Data were collected from 60 food handlers through validated questionnaire. Respondents were grouped into two cathegories : a. Teaching Hospital, and b.Non- teaching Hospital. Data were collected in February-April 2017. Most of food handlers (80\%) were graduated from vocational senior high school (SMK). Respondent's age were 28-37 years $(36.7 \%)$ in average. Most of respondent's work experience $(85 \%)$ was less than 15 years. The result showed that more than $80 \%$ of food handlers have good knowledge in safe food handling procedures, good attitude $(66 \%)$ and good practices $(90 \%)$. There was no significant difference of knowledge, attitude and practices between two groups. Results strongly emphasize the need of food hygiene training of hospital food handlers. It also suggest that non food handlers such as nurse or kitchen supervisor should involved in the training. Some aspects of food handlers' safety behavior need to be emphasized.
\end{abstract}

Copyright $\odot 2017$ Institute of Advanced Engineering and Science. All rights reserved.

\section{Corresponding Author:}

Daru Lestantyo,

PhD Department, Faculty of Medicine,

Gadjah Mada University,

Jogjakarta, Indonesia.

Email: daru71@gmail.com

\section{INTRODUCTION}

Food borne diseases are still common problems in all over asian countries. It mainly caused by the oral route of microorganism or toxin which produced by pathogenic bacteria in sufficient amount to develop pathologic conditions. Research showed that lack of knowledge and food mishandling were identified as cause of food poisoning [1]. Knowledge, Attitude and Practice (KAP) of food handlers is believed have influence in food poisoning cases. Aycicek et al found that $S$. aureus contamination in healthcare facilities was contributed by food handlers' personal hygiene [2]. Hospital kitchen cater a large population consisted of patients, doctor, nurses and many visitors. Ready to eat food prepared in hospital were in large quantities and is more susceptible to contamination. Food handlers play an important role in prevention of food borne diseases. They have to ensure hygiene standards of preparation, process and food serving but they also do not realized could carry some foodborne pathogens such as E. coli, Salmonella Spp, S.aureus and Shigella in their bodies in particular on their skin or nose [3].

Poor food hygienic practices could contribute food borne diseases in hospital. Food handlers who were $S$ aureus carrier and have direct contact with prepared food can contaminate pathologic organism to 
hospital inpatients [4]. Study showed that there was a significant correlation between personal hygiene and microbial status of food handler's. Several studies stated that hospital food poisoning could be a real threat to hospital quality assurance [5]. Food poisoning could results in hospital huge financial losses and public confidence.

Food hygiene training are needed to improve hospital food handler's knowledge, even though this does not always change employee's behavior. Most of studies suggest to improve food handler's knowledge, attitude and practice in food hygiene [6]. In Indonesia, Ministry of Health still does not implemented HACCP for hospital kitchen yet. This increases the importance of safe food handling standards for hospital.

\section{RESEARCH METHOD}

The aim of this study is to describe food handler's knowledge, attitude and practice amongst hospital food handler and compare it between two groups. Regarding the groups to be compared, the respondents classified as teaching hospital and non teaching hospital food handlers. As mentioned earlier, the participants were divided into two groups. Teaching hospital represented food handlers whose trained frequently. Non teaching hospital represented of food handlers whose trained infrequently for purpose of analysis. By comparing training experiences of the groups, the study would be able to analyze participant's knowledge in food hygiene respectively. Although food safety training program are still limited, hospital has to served patients and employees with a valuable standard.

This is a cross sectional study conducted in two hospitals of Central Java Province. The study was carried out between February - April 2017 amongst food handlers working in 2 hospital kitchen in Central Java Province. A non probability sampling was conducted in this study. 60 food handlers were participated in this study. All participants either had direct contact and or delivering foods and divided into two groups which consists of 30 participants each. The questionaire consists of three parts; knowledge, attitude and practice. It were mainly contained multiple choice questions. Each questions in knowledge part consisted of two optional answer of "yes" or "no". The knowledge questionnaire used to asses food safety knowledge. It was organized into three main sections i) basic food hygiene, ii) safety and health, iii) HAIs prevention. It was filled either by participants or field enumerator. The questionnaire were developed on the basis of regulations and guidelines of The Indonesian Ministry of Health with adaptations from previous studies.

The questionnaires items for attitude questions were rated on a 5-point Likert Scale from 1 (Strongly Agree/Always) to 5 (Strongly Disagree/Never). Attitude questionnaire were developed to track i) personal hygiene, ii) safety and health opinions. Practice questionnaires consisted of two optional answer which designed to determine employees' obedient on food hygiene practice. The content validation and reliability of the questionnaires was done by statistical test with Cronbach's alfa for each number of questions. All study member team were trained to ensure consistent interviewing completeness standards.

The questionnaire were delivered to all participants after working hours. All participants replied to the questionnaire. The interview was carried after finishing their jobs to ensure participants complete their questionnaire without distraction from their duties. Statistical analysis was performed using computer statistics software. Descriptive statistics was used to summarize the general characteristics of participants and to describe interview results of knowledge, attitude and practice. Independent $t$ test was performed to compare means between two unrelated groups. The study protocols was reviewed and approved by Ethics Committee Of Faculty Of Public Health, Diponegoro University.

\section{RESULTS AND ANALYSIS}

\subsection{Food handler's profile}

A greater number of participants in group 1 were in the age bracket $48-57$ years and in group 2 were 28-37 years. The average age was 28.5 years ini group 1 and 23.6 in group 2. Working experience was 2.32 years in group 1 and 12 years in group 2 . All of participants $(100 \%)$ were female. Table 1 shows that most participants $(36.7 \%)$ in both groups had completed vocational high school $(S M K)$ in food processing. Some of them were graduated from faculty of nutritional sciences. Surprisingly, our study found that there were 11 participants in group one graduated from Primary and Junior High School (SD and SMP ). 
Table 1. Participants' Profile

\begin{tabular}{llcccc}
\hline & \multirow{2}{*}{ Cathegory } & \multicolumn{2}{c}{ Frequency } & \multicolumn{2}{c}{ Percentage } \\
& & Group 1 & Group 2 & Group 1 & Group 2 \\
\hline Gender & Male & 0 & 1 & 0 & 3.3 \\
& Female & 30 & 29 & 100 & 96.7 \\
& & & & & \\
& $18-27$ & 5 & 7 & 16.7 & 23.3 \\
& $28-37$ & 4 & 20 & 36.7 & 66.7 \\
Working & $38-47$ & 4 & 3 & 13.3 & 10 \\
experiences & $48-57$ & 17 & 0 & 33.3 & 0 \\
& $1-15$ & & & & \\
\multirow{5}{*}{ Education } & $16-30$ & 12 & 27 & 40 & 90 \\
level & $31-45$ & 12 & 3 & 40 & 10 \\
& & 6 & 0 & 20 & 0 \\
& Primary School & & & & 10 \\
& Junior High School & 3 & 0 & 26.7 & 0 \\
& Senior Middle School & 8 & 0 & 16.7 & 23.3 \\
& Senior Vocational School & 5 & 7 & 36.7 & 36.7 \\
& College & 1 & 16 & 3.3 & 16,7 \\
& Bachelor & 2 & 5 & 6.7 & 6.7 \\
\hline
\end{tabular}

\subsection{Knowledge}

In common, participants's knowledge mean percentage score was 14.933 SD 1.94 in group 1 and 15.033 SD 2.17 in group 2. All participants $(100 \%)$ in group 1 have answered correctly in "washing vegetables as a risk in food process" statement and "eat leftover cooked food could cause food poisoning". Contrary, a lack of food hygiene knowledge was found in other questions. 83.3\% in group 1 and $60 \%$ in group 2 have uncorrect answer in pathogenic microbes as agent of food poisoning. All participants in group 2 agreed that food contact with bare hands could cause food poisoning but $20 \%$ of respondents in group 1 did not agree with the same statement. Table 2 shows the food handler's knowledge. Independent $\mathrm{t}$ test showed there was no significant differences of knowledge between participants in group 1 and group 2 ( $p$ 0.852). $\mathrm{Tab}$

Table 2. Food Handler's Knowledge

\begin{tabular}{|c|c|c|c|c|c|c|}
\hline \multirow{2}{*}{ No } & \multirow{2}{*}{ Statement } & \multirow{2}{*}{ Answer } & \multicolumn{2}{|c|}{ Group 1} & \multicolumn{2}{|c|}{ Group 2} \\
\hline & & & $\mathrm{F}$ & $\%$ & $\mathrm{~F}$ & $\%$ \\
\hline \multirow[t]{2}{*}{1} & \multirow[t]{2}{*}{ Food poisoning is caused only by pathogenic microbes } & Correct & 5 & 16.7 & 12 & 40 \\
\hline & & Not correct & 25 & 83.3 & 18 & 60 \\
\hline 2 & Eating raw or half cooked food is highly risk for food poisoning & Not correct & 4 & 13.3 & 3 & 10 \\
\hline \multirow[t]{2}{*}{3} & \multirow[t]{2}{*}{ Unwashed vegetables have many risks of food contamination } & Correct & 30 & 100 & 28 & 93.3 \\
\hline & & Not correct & 0 & 0 & 2 & 6.66 \\
\hline \multirow[t]{2}{*}{5} & \multirow{2}{*}{$\begin{array}{l}\text { Eating leftover cooked food for more than } 6 \text { hours is at high risk to } \\
\text { cause food poisoning }\end{array}$} & Correct & 30 & 100 & 25 & 83.3 \\
\hline & & Not correct & 0 & & 5 & 16.7 \\
\hline \multirow[t]{2}{*}{6} & \multirow{2}{*}{$\begin{array}{l}\text { Keeping food at refrigeratorhelps to prevent bacterial } \\
\text { contamination }\end{array}$} & Correct & 23 & 76.6 & 22 & 73.3 \\
\hline & & Not correct & 7 & 23.3 & 8 & 26.6 \\
\hline 7 & $\begin{array}{l}\text { Contacting ready to eat food with bare hands might cause } \\
\text { foodborne infections }\end{array}$ & Correct & 24 & 80 & 30 & 100 \\
\hline 9 & $\begin{array}{l}\text { Food poisoning could cause severe diseases that end in } \\
\text { hospitalization and sometimes death }\end{array}$ & Not correct & 1 & 3.33 & 5 & 16.7 \\
\hline \multirow[t]{2}{*}{10} & \multirow[t]{2}{*}{ Healthy foodhandlers might carry foodborne pathogens } & Correct & 28 & 93.3 & 29 & 96.7 \\
\hline & & Not correct & 2 & 6.66 & 1 & 3.33 \\
\hline \multirow[t]{2}{*}{11} & \multirow{2}{*}{$\begin{array}{l}\text { Insect such as cockroaches and flies mght transmit foodborne } \\
\text { pathogens }\end{array}$} & Correct & 28 & 93.3 & 27 & 90 \\
\hline & & Not correct & 2 & 6.66 & 3 & 10 \\
\hline
\end{tabular}

\subsection{Attitude}

Table 3 shows the results of food handler's respon on attitude questions. Our study proved that food handler's attitude towards safe food handling score was 72.97 SD 8.75 in group 1 and 73.93 SD 7.25 in group 2. Independent $t$ test result showed that there was no significance differences of food handler's attitude in both group ( $p$ 0.64). 56.7\% of participants in group 1 disagree that they should cut raw vegetables with 
different cutting board, but contrary $63.3 \%$ of participants in group 1 agree that theu should not cut raw vegetables by same cutting knife. Most of participants agree that they should be medically examined every six months.

Table 3. Food Handler's Attitude

\begin{tabular}{|c|c|c|c|c|c|c|}
\hline \multirow{2}{*}{ No } & \multirow{2}{*}{ Statement } & \multirow{2}{*}{ Answer } & \multicolumn{2}{|c|}{ Group 1} & \multicolumn{2}{|c|}{ Group 2} \\
\hline & & & $\mathrm{f}$ & $\%$ & $\mathrm{f}$ & $\%$ \\
\hline \multirow[t]{5}{*}{1} & Safe Food handling is an important part of my job & SA & 9 & 30 & 10 & 30 \\
\hline & & A & 19 & 63.3 & 18 & 60 \\
\hline & & $\mathrm{N}$ & & & & \\
\hline & & $\mathrm{D}$ & 2 & 6.66 & 2 & 6.66 \\
\hline & & SD & & & & \\
\hline \multirow[t]{5}{*}{2} & Food Safety courses should be conducted every year & SA & 11 & 36.6 & 10 & 30 \\
\hline & & A & 17 & 56.7 & 18 & 60 \\
\hline & & $\mathrm{N}$ & & & & \\
\hline & & $\mathrm{D}$ & 2 & 6,66 & 2 & 6,66 \\
\hline & & SD & & & & \\
\hline \multirow[t]{5}{*}{3} & Raw food should be kept separately from cooked foods & SA & 19 & 63,3 & 20 & 70 \\
\hline & & A & 11 & 36.6 & 10 & 30 \\
\hline & & $\mathrm{N}$ & & & & \\
\hline & & $\mathrm{D}$ & & & & \\
\hline & & SD & & & & \\
\hline \multirow[t]{5}{*}{4} & Food handlers can be a source of food borne diseases & SA & 5 & 16,6 & 6 & 20 \\
\hline & & A & 19 & 63.3 & 18 & 60 \\
\hline & & $\mathrm{N}$ & 3 & 10 & 3 & 10 \\
\hline & & $\mathrm{D}$ & 3 & 10 & & \\
\hline & & SD & & & 3 & 10 \\
\hline \multirow[t]{5}{*}{5} & Wiping vegetables or fruits make them safe to be eaten & SA & 4 & 1.33 & 2 & 6.66 \\
\hline & & A & 5 & 16,7 & 3 & 10 \\
\hline & & $\mathrm{N}$ & 7 & 23.3 & & \\
\hline & & $\mathrm{D}$ & 13 & 43.3 & 19 & 63.3 \\
\hline & & SD & 1 & 3.33 & & \\
\hline \multirow[t]{5}{*}{6} & Male Food handlers should not have beards or moustache & SA & 10 & 30 & 12 & 40 \\
\hline & & A & 12 & 40 & 14 & 46.7 \\
\hline & & $\mathrm{N}$ & 2 & 6.66 & 1 & 3.33 \\
\hline & & $\mathrm{D}$ & 6 & 20 & 2 & 6.66 \\
\hline & & SD & & & 1 & 3.33 \\
\hline \multirow[t]{5}{*}{7} & Female food handlers should not have long nails & SA & 19 & 63.3 & 16 & 53.3 \\
\hline & & A & 11 & 36.6 & 14 & 46.7 \\
\hline & & $\mathrm{N}$ & & & & \\
\hline & & $\mathrm{D}$ & & & & \\
\hline & & SD & & & & \\
\hline \multirow[t]{4}{*}{8} & Raw vegetables and meat should not be cut on the same knife & SA & 19 & 63.3 & 19 & 63.3 \\
\hline & & $\begin{array}{l}\mathrm{A} \\
\mathrm{N}\end{array}$ & 9 & 30 & 8 & 26.6 \\
\hline & & $\mathrm{D}$ & 2 & 6.66 & 3 & 10 \\
\hline & & SD & & & & \\
\hline \multirow[t]{6}{*}{9} & Raw vegetables and meat should not be cut on the same & SA & 2 & 6.66 & 2 & 6.66 \\
\hline & cutting board & A & & & 3 & 10 \\
\hline & & $\mathrm{N}$ & 4 & 13.3 & & \\
\hline & & $\mathrm{D}$ & 17 & 56.7 & 19 & 63.3 \\
\hline & & SD & 6 & 20 & 6 & 20 \\
\hline & & SA & 13 & 43.3 & 15 & 50 \\
\hline \multirow[t]{4}{*}{10} & Food handlers should be medically examined every six & A & 17 & 56.7 & 15 & 50 \\
\hline & months & $\mathrm{N}$ & & & & \\
\hline & & $\mathrm{D}$ & & & & \\
\hline & & SD & & & & \\
\hline
\end{tabular}

\subsection{Practice}

The results of practice questions are displayed in Table 4. Of The total participants, $100 \%$ would wash their hands before preparing foods in both group, but only $93.3 \%$ ( in both group) of participants wash their hands after preparing foods. Our study also found 6 (20\%) out of 30 people still work when have lesions on the hands. $93.3 \%$ participants in group 1 and $66.7 \%$ in group 2 would still work even though they have diarrhea symptoms.

In general, food handler's practice towards safe food handling was high with mean percentage score of 13.43 SD 1.65 in group 1and 13.63 SD 1.75 in group 2. Independent t test result showed that there was no significance differences of food handler's practice in both group $(p 0.16)$. 
Table 4. Food Handler's Practice

\begin{tabular}{|c|c|c|c|c|c|c|}
\hline \multirow{2}{*}{ No } & \multirow{2}{*}{ Statement } & \multirow{2}{*}{ Answer } & \multicolumn{2}{|c|}{ Group 1} & \multicolumn{2}{|c|}{ Group 2} \\
\hline & & & $\mathrm{f}$ & $\%$ & $\mathrm{~F}$ & $\%$ \\
\hline \multirow[t]{2}{*}{1} & \multirow[t]{2}{*}{ Wearing Gloves when handle ready -to-eat food } & Positive & 29 & 96.6 & 28 & 93.3 \\
\hline & & Negative & 1 & 3.33 & 2 & 6.66 \\
\hline \multirow[t]{2}{*}{2} & \multirow{2}{*}{$\begin{array}{l}\text { Washing hands with water and soap before preparing } \\
\text { foods }\end{array}$} & Positive & 30 & 100 & 30 & 100 \\
\hline & & Negative & 0 & & 0 & \\
\hline \multirow[t]{2}{*}{3} & \multirow[t]{2}{*}{ Washing hands with water and soap after preparing foods } & Positive & 28 & 93.3 & 28 & 93.3 \\
\hline & & Negative & 2 & 6.66 & 2 & 6.66 \\
\hline \multirow[t]{2}{*}{4} & \multirow[t]{2}{*}{ Still work when have diarrhea symptoms } & Positive & 2 & 6.66 & 10 & 33.3 \\
\hline & & Negative & 28 & 93.3 & 20 & 66.7 \\
\hline \multirow[t]{2}{*}{5} & \multirow[t]{2}{*}{ Work when have lesions on the hands } & Positive & 24 & 80 & 22 & 73.3 \\
\hline & & Negative & 6 & 20 & 8 & 26.7 \\
\hline \multirow[t]{2}{*}{6} & \multirow[t]{2}{*}{ Allow finger nails to grow } & Positive & 30 & 100 & 30 & 100 \\
\hline & & Negative & 0 & & & \\
\hline \multirow[t]{2}{*}{7} & \multirow[t]{2}{*}{ Wash Vegetables before slicing } & Positive & 29 & 96.6 & 29 & 96.6 \\
\hline & & Negative & 1 & 3.33 & 1 & 3.33 \\
\hline \multirow[t]{2}{*}{8} & \multirow{2}{*}{$\begin{array}{l}\text { Keep cooked meat at room temperaturefor more than } 4 \\
\text { hours }\end{array}$} & Positive & 19 & 63.3 & 20 & 66.7 \\
\hline & & Negative & 11 & 36.6 & 10 & 33.3 \\
\hline \multirow[t]{2}{*}{9} & \multirow[t]{2}{*}{ Keep working when have common colds } & Positive & 25 & 83.3 & 25 & 83.3 \\
\hline & & Negative & 5 & 16.6 & 5 & 16.7 \\
\hline \multirow[t]{2}{*}{10} & \multirow{2}{*}{$\begin{array}{l}\text { Wear fully equipped Personal Protective Equipment } \\
\text { when on duty }\end{array}$} & Positive & 29 & 96.6 & 29 & 96.7 \\
\hline & & Negative & 1 & 3.33 & 1 & 3.33 \\
\hline
\end{tabular}

\section{DISCUSSION}

There were a lot of studies of food handlers or food hygiene in the past decade but only a few focused in hospital [7]. Most studies suggested that improper food handling lead to approximately $80 \%-90 \%$ of food poisoning. This study showed that the education level and working experiences had different results in safe food handling knowledge, attitude and practice. It is interesting to observe that participants who have lower education level (primary and junior high school) performed not worse than those who graduated from senior high school, colleges or higher education. Our study showed that only $40 \%$ of food handlers ingroup 2 chose the correct answers in food borne diseases question. It indicated that $60 \%$ of participants have a poor knowledge in workplace hazards. Previous studies found that food hygiene training increased participant's knowledge regarding food borne diseases issues [8]. Training will result knowledge and attitude increases but rare improves in behavior change [9]. Recent studies also reveal that lack of personal hygiene knowledge in food handlers could result food poisoning incidents [10].

Information which disseminated in training program must meet target audience's information need. Studies indicated that food hygiene information must contained risk communications. People with less ignorance on food hygiene were a vulnerable population. Many studies reported that food handlers of various ages think that they know how to handle food safely, but their practice did not prove it [11]. Food handlers with younger ages and/or lack of formal knowledge more likely to have risky food hygiene behavior than others. Insufficient training in food hygiene will lead to inadequate food handling practice [12]. Allam et al found in their study that low educational levels will make food handlers unaware of food safety practices [13] In Indonesia, food hygiene training is an obligation for hospital food service facility. All food service authorities in Indonesia must implement continuous courses in safe food handling.

In general, our study showed that participants's knowledge in safe food handling is quite high. Majority of participants agreed that safe food handling had to be implemented in their daily routine job. Ironically, some questions in microbiological aspects of safe food handling were answered wrong by respondents (83.3\% in group 1 and $60 \%$ in group 2). Study in Ghana proved that $76.2 \%$ of respondents did not know that Salmonella is a food borne pathogens [14]. Another research in Malaysia reveal that approximately $71.4 \%$ of respondents did not know that $S$. aureus is an agent of foodborne diseases [8]. Education level will influenced respondent's knowledge but in some cases, some risky practices being more common within higher education level [4]. Research in India showed that that knowledge on food hygiene was not always significantly increase among workers with higher knowledge [15].

If we looked at the attitude of respondents there were various answers in safe food handling perceptions. The study reveal that even though 63.3\% (group 1) agreed that safe food handling is an important part of their job only $16.7 \%$ (group 1) believe that wiping vegetables and fruits could prevent food borne microbes contaminations. From past studies we learn that the most food hygiene abused were : wearing clean uniform, having long nails, uncovered food and washing hands after visiting toilet [7]. Literatures

IJPHS Vol. 6, No. 4, December 2017 : $324-330$ 
showed that food hygiene course will raise awareness of knowledge in food safety but failed to change behaviour [16].

Majority of participants were familiar with food hygiene concepts of separate process and materials. The term 'separate' referred to raw food and cooked food, different workspaces and different tools. Although there were acquaintance in separating things but it did not reflected in their answers. Our study showed that $63.3 \%$ of participants (group 1 and 2) agreed that they should not cut raw vegetables and meat with same knife but only $6.66 \%$ (in both group) agreed that raw vegetables and meat should not be cut in same cutting board. Using the same cutting board can cause cross contamination between raw vegetables and meat [17]. In some researchs, food handlers had poor knowledge and attitude for food hygiene [18]. Although hospital food handlers were reported to exhibit good personal hygiene, however they were negligence to compliance with adequate hygiene practices [19]. In common, our studies found that majority of respondents have good practice in food hygiene. However, $16.6 \%$ keep working when they have common cold. The result showed that even though the score was high in knowledge and attitude, respondents did not totally perform food hygiene practices. Our study revealed a discrepancy between knowledge and practice in food safety behaviour. Research in Turkey found that even though all participants have strong believe that food safety is an important part of their job, but it never implemented in daily work [20].

Many factors were related to food hygiene compliance. Those are available of supplies (gloves, soap, towels), worker busyness and food safety procedures [21]. A high standard of personal hygiene practices among participants is needed. Pandita et al found that only $20 \%$ of employees wear complete required PPE [15]. Same result was reported by Kasturwar's research. Only $22.89 \%$ female employees keep mouth, nose and hair covered [3]. Studies found that having good knowledge and attitude will lead to good practices. However some studies also found contradicts with the results. They found that good knowledge in food hygiene did not consequently leads to good food handling practices [1],[11]. There were some common hygiene abused in food safe handling. Our study found that some employees will keep working when they have diarrhea symptoms. Research in India found that $12.96 \%$ of food handlers were found suffering from tuberculosis, leprosy and skin diseases [22]. Most of food handlers who belongs to below under poverty line in developing countries were found suffered from many diseases. Working under bad health condition is one of the most commonly reported practices.

\section{CONCLUSION}

This study revealed food safety behavior in hospital kitchen staffs. There were no significant statistical mean diferences between teaching and non teaching hospitals on knowledge, attitude and practice. Though the study result indicated a positive knowledge in food hygiene but their practice was average. It is recommended for hospital kitchen supervisor to conduct food and personal hygiene training. Hospital management should build food safety behavior amongst food handlers to ensure the safety of food consumed by patients and healthcare workers.

Nevertheless, our study revealed a general positive attitude toward food hygiene involving using adequate clothing and PPE and hand hygiene. Food safety in hospital needs special attention to definite preventive action regarding minimize the hazard of microbes and chemical contaminations.

\section{ACKNOWLEDGEMENTS}

We acknowledge students of Faculty of Public Health, Diponegoro University for cooperation during the study and food handlers who participated in this study

\section{REFERENCES}

[1] Sharif L. and Obaidat M. M., "Food Hygiene Knowledge, Attitudes and Practices of the Food Handlers in the Military Hospitals," Food Nutr Sci., vol. 4, pp. 245-51, 2013.

[2] Ayçiçek H., et al., "Assessment of the bacterial contamination on hands of hospital food handlers," Food Control, 2004.

[3] Nb K. and Shafee M., "Knowledge, Practices and Prevalence of MRSA among Food Handlers," Int J Biol Med Res., vol/issue: 2(4), pp. 889-94, 2011.

[4] Garcia P. P. C., et al., "The Efficacy of Food Handler Training: The Transtheoretical Model in Focus, Brazil, 2013," J Saf Stud., vol/issue: 1(2), pp. 11, 2015

[5] Mukhopadhyay P., et al., "Identifying Key Risk Behaviors Regarding Personal Hygiene and Food Safety Practices of Food Handlers Working in Eating Establishments Located Within a Hospital Campus in Kolkata," vol. 5, pp. 21-8, 2012.

[6] da Cunha D. T., et al., "The role of theoretical food safety training on Brazilian food handlers' knowledge, attitude and practice," Food Control, vol. 43, pp. 167-74, 2014.

Safe Food Handling Knowledge, Attitude and Practice of Food Handlers in Hospital .... (Daru Lestantyo) 
[7] Githiri M., et al., "Knowledge in food hygiene and hygienic practices differ- in food handlers at a hospital in Nairobi, Kenya," African J Food Sci Technol., vol/issue: 4(1), pp. 19-24, 2013.

[8] Abdullah S. N. and Siow O. N., "Knowledge, attitudes and practices of food handlers on food safety in food service operations at the Universiti Kebangsaan Malaysia," Food Control, vol/issue: 37(1), pp. 210-7, 2014.

[9] Pilling V. K., et al., "Identifying Specific Beliefs to Target to Improve Restaurant Employees' Intentions for Performing Three Important Food Safety Behaviors," J Am Diet Assoc., vol/issue: 108(6), pp. 991-7, 2008.

[10] Seaman P., "Food hygiene training: Introducing the Food Hygiene Training Model," Food Control, vol/issue: 21(4), pp. 381-7, 2010.

[11] Hassan H. F. and Dimassi H., "Food safety and handling knowledge and practices of Lebanese university students," Food Control, vol/issue: 40(1), pp. 127-33, 2014.

[12] Jianu C. and Chiş C., "Study on the hygiene knowledge of food handlers working in small and medium-sized companies in western Romania," Food Control, vol/issue: 26(1), pp. 151-6, 2012.

[13] Allam H. K., et al., "Hand Contamination among Food Handlers," vol/issue: 13(5), pp. 1-8, 2016.

[14] Akabanda F., et al. "Food safety knowledge, attitudes and practices of institutional food-handlers in Ghana," BMC Public Health, vol/issue: 17(1), pp. 40, 2017.

[15] Pandita K. K., et al., "A Study of impact of Education on Awareness , Personal Hygiene and Practices of food handlers of a Tertiary Care Hospital in Kashmir, India," Glob J Med Public Heal., vol/issue: 2(2), 2013.

[16] Lee H., et al., "Assessment of Food Safety Knowledge, Attitude, Self-Reported Practices, and Microbiological Hand Hygiene of Food Handlers," Int J Environ Res Public Health, vol/issue: 14(1), pp. 55, 2017.

[17] Ar I., et al., "Food Hygiene And Safety Practices Of Food Service Staff In University Of Benin Teacing Hospital, Benin City, Nigeria," J Biomed Res., vol/issue: 12(2), pp. 69-76, 2013.

[18] Siau M. F., "Food court hygiene assessment and food safety knowledge, attitudes and practices of food handlers in Putrajaya," Int Food Res J., vol/issue: 22(5), pp. 1843-54, 2015.

[19] Martins R. B., et al., "Knowledge on food hygiene of food service staff working in nursing homes and kindergartens in Porto region - Portugal," Food Control, vol. 42, pp. 54-62, 2014.

[20] Tokuç B., et al., "Knowledge, attitudes and self-reported practices of food service staff regarding food hygiene in Edirne, Turkey," Food Control, vol/issue: 20(6), pp. 565-8, 2009.

[21] Green L. R., et al., "Factors related to food worker hand hygiene practices," J Food Prot., vol/issue: 70(3), pp. 661-6, 2007.

[22] Mudey A. B., "Health Status and Personal Hygiene among Food Handlers Working at Food Establishment around a Rural Teaching Hospital in Wardha District of Maharashtra, India," Glob Journals Heal Sci., vol/issue: 2(2), pp. 198-206, 2010. 